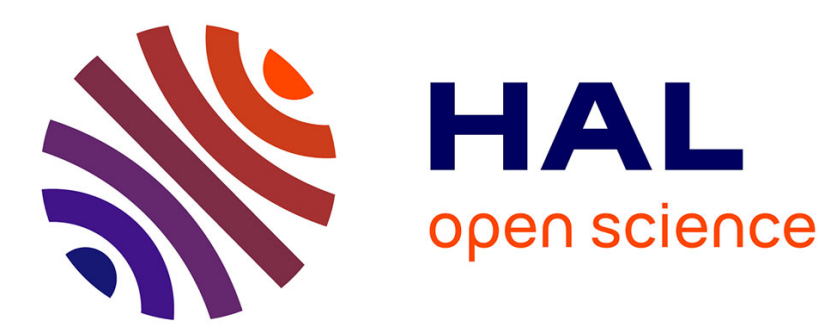

\title{
An Alternative to Cartesianism? Plotinus's Self and its Posterity in Ralph Cudworth
}

\author{
Gwenaëlle Aubry
}

\section{To cite this version:}

Gwenaëlle Aubry. An Alternative to Cartesianism? Plotinus's Self and its Posterity in Ralph Cudworth. F. Leigh. Self-Knowledge in Ancient Philosophy, Oxford University Press, pp.210-230, 2020, 10.1093/oso/9780198786061.003.0010 . hal-02861181

\section{HAL Id: hal-02861181 \\ https://hal.science/hal-02861181}

Submitted on 6 Jul 2020

HAL is a multi-disciplinary open access archive for the deposit and dissemination of scientific research documents, whether they are published or not. The documents may come from teaching and research institutions in France or abroad, or from public or private research centers.
L'archive ouverte pluridisciplinaire HAL, est destinée au dépôt et à la diffusion de documents scientifiques de niveau recherche, publiés ou non, émanant des établissements d'enseignement et de recherche français ou étrangers, des laboratoires publics ou privés. 


\title{
10
}

\section{An Alternative to Cartesianism? Plotinus's Self and its Posterity in Ralph Cudworth}

\author{
Gwenaëlle Aubry
}

What the different contemporary criticisms of reflexive philosophy have in common is that they all call into question the post-Cartesian idea according to which the self has a privileged relationship to itself. ${ }^{1}$ What is thus questioned is the possibility of an immediate and evident access to interiority, provided by self-consciousness, as well as that of a knowledge based on such consciousness. As Charles Larmore recently wrote, the notion of internal sense, as well as the idea of self-knowledge that is based on it, amounts to inventing an entirely unintelligible capacity, since it is meant to provide a self-apprehension deprived of the two distinctive features of knowledge as a whole (distinction between subject and object, possibility of error).' ${ }^{2}$ Such challenges urge us to examine the history of self-knowledge and, more precisely, of the articulation of the relations between self-knowledge, self-consciousness, and interiority. Far from being immediate or obvious, this articulation, which can be found in Descartes, is the result of an elaboration. In Platonic philosophy, for instance, the injunction to self-knowledge, the Delphic precept, is dissociated from the ideas of immediate reflexivity and of interiority. ${ }^{3}$ More generally, it has been shown that the ancient self was to be found not as much in the dimension of interiority and self-consciousness as in that of exteriority and manifestation. This is why Jean-Pierre Vernant could write that the self existed for the Greeks essentially in act, in energeia:

L'individu se situe lui-même dans les opérations qui le réalisent, qui l’effectuent 'en acte', energeia, et qui ne sont jamais dans sa conscience. Il n'y a pas d'introspection. Le sujet est extraverti. Il se regarde au-dehors. Sa conscience de

\footnotetext{
${ }^{1}$ One can find them summed up for instance in J.-C. Billier's Introduction to Descombes and Larmore, 2009.

${ }^{2}$ Descombes and Larmore, 2009, 105.

3 About the history of the 'Know Thyself' and the tradition of the First Alcibiades, see Courcelle, 1974; J. Pépin, 1971. In Plotinus: G. O’Daly, 1973, chap. 1.
} 
soi n'est pas réflexive, elle n'est pas repli sur soi, travail sur soi, élaboration d'un monde intérieur, intime, complexe et secret, le monde du 'Je'. Elle est existentielle. $^{4}$

This description partly resumes the analysis of Jacques Brunschwig in a paper disconcertingly entitled 'Aristote et l'effet Perrichon, ${ }^{5}$ published in a collective volume in honour of the famous Cartesian scholar Ferdinand Alquié. Brunschwig wonders about Aristotle's assertion that the producer is in act in his work. ${ }^{6}$ For a modern, such an assertion is, he says, somehow 'wild and absurd': that my work should be something of me, fine, but how could it be me? Yet this assertion, according to Brunschwig, enables us to grasp an essential feature of the ancient self: it leads one on the path of 'a kind of paradoxical cogito which could be put in the following words: I can see me (in my work), therefore I am; and I am where I see me; I am this projection of myself which I see." It is through act, exteriority, manifestation, that the Greek self would achieve self-knowledge and self-identification. A parallel to this analysis is found in the work of Michel Foucault, who has shown how, in Platonic thought in particular and ancient thought in general, the gnothi seauton was subordinated to the epimelei heautou, self-knowledge to self-care, and how the philosophical requalification of self-knowledge-the accentuation of the cognitive dimension of the self's relationship to itself-should be considered as a distinctive feature of modernity and a consequence of the 'Cartesian moment. ${ }^{8}$ It can also be connected with Christopher Gill's characterization of the ancient self as 'objective-participant' rather than 'subjective-individualist.' These various analyses converge in acknowledging the primacy, for the ancient idea of the self, of exteriority (act, action, alterity, norms, and values adopted by a community or postulated in a universal), but also (and this is why they can be compared to those of Foucault $)^{10}$ in the description of a relationship to oneself that is not primordially cognitive.

If these analyses are worth recalling, it is because they can help to better appreciate the singular position which Plotinus represents in this context, and which I shall, to begin with, try to evaluate. It can be characterized in the following way:

- First, Plotinus associates self-knowledge with interiority. More precisely, the precondition of self-knowledge is the conversion to interiority. But this interiority is not 'subjective', much less, 'intimate'. It bears or contains the very principles of reality, from the One-Good to Nature.

\footnotetext{
${ }^{4}$ Vernant, 1996, 73-93, 91. See also Vernant, 1989, which receives further discussion in Aubry and Ildefonse, 2008, 9-16.

${ }^{5}$ Brunschwig, 1983, 360-77. $\quad{ }^{6}$ Eth. Nic. IX, 1168a7. $\quad{ }^{7}$ Brunschwig, 1983, 375.

${ }^{8}$ Foucault, 2001. ${ }^{9}$ Gill, $2006 .{ }^{10}$ Gill, 2006, 348-51.
} 
- Second, the 'I', which Plotinus (and this plural is significant) calls the 'we', the hemeis, does have immediate access to itself; in other words, Plotinus does accept an immediate reflexivity. But this self-consciousness is not self-knowledge. First, because it does not give access to a unity, but to the multiplicity which constitutes the hèmeis. Second, because this multiplicity is not essential. Rather, the hemmeis perceives itself as made up of multiple powers, only one of which (the intellect or the separate soul) constitutes its essence. This is why self-consciousness is not primarily a revelation of the essence, but rather of distance from the essence.

- This is also why a distinction must be made between the subject of selfconsciousness (the hemeis and, along with it, the dianoia) and the subject of self-knowledge (the intellect or separate soul). In other words, one has to distinguish between two modalities of self-knowledge, only the second of which is genuine knowledge. Indeed, at the level of the intellect, self-knowledge is really the soul's coincidence with its essence and, beyond it, with the totality of ousia (or with the Intellect-principle).

- This leads me to my last point: unlike the separate soul, the hemmeis is not an ousia. It is not adequate to its essence, nor is it a substance in the sense of the permanent substrate of attributes and qualities. Associated with (but not identical to) consciousness, situated more than defined, it is, in fact, that which, depending on the orientation it gives to its consciousness, identifies itself with one or the other of the powers in which it consists.

I would like to develop these various points, according to the fundamental distinction between two modes of self-knowledge: in soul, and in Intellect. At the same time, I shall try to emphasize the dissociations of the conceptual relations and equivalences inherited from the 'Cartesian moment': between self-knowledge and self-consciousness, but also between self and substance, or between self and identity. I would thus like to show how Plotinus, although, of course, he is not a 'modern', is no longer an 'ancient' either: how, in particular, he no longer associates the hemeis with energeia, but with dunamis, not with act, but with power and potentiality.

Finally, I shall try to identify the echoes of this singular conception of the self in the work of a modern who also is, in many respects, a Cartesian: Ralph Cudworth. A Cambridge Platonist, and great reader of Plotinus, Cudworth (who first used the words 'internal sense' and 'pyschology') presents, against Descartes, a theory of the self which dissociates thought from consciousness in order to characterize the self, more fundamentally, as a continuous generative power and a tension towards the Good. 


\section{Self-Knowledge in the Soul}

Plotinus immediately associates the injunction to self-knowledge with the question of the one and the many. From the outset, therefore, self-knowledge is graduated according to the levels of reality. Thus, it applies only to an inferior degree of being, characterized by multiplicity:

... 'Know yourself' is said to those who because of their selves' multiplicity have the business of counting themselves up and learning that they do not know all of the number and kind of things they are, or do not know any one of them, nor what their ruling principle is or by what they are themselves.

$$
\left(\text { VI.7 [38], 41. 21-25) }{ }^{11}\right.
$$

To know oneself does not amount to grasping one's essence, unity, or identity, but to counting up the multiplicity in which one consists, organizing it into a hierarchy, and, finally, determining what, in this multiplicity, is properly 'ourselves'. We have here three distinct operations, which are so many successive declensions of the Delphic precept: 'Know how many you are'; 'Know what governs in you'; 'Know what in you is really you'. Self-knowledge can be achieved only at the end of this process of counting, hierarchization, and internal selection.

Indeed, such knowledge requires, as its very first condition, a conversion to interiority which is also an estrangement from the body and from the primary testimony to its union with the soul: sensation. Thus, as long as we exercise only our sense faculty, 'we do not know ourselves yet', we know only 'part of our soul', whereas we are 'the whole soul'. In order to have a perception (antilēpsis) of this latter, we must 'turn our power of apprehension inwards' (V.1 [10], 12. $8-13)$.

Thus, although it presupposes a conversion to interiority, self-knowledge is not merely an access to a unity. What this conversion allows the subject to grasp is 'the whole soul', that is, a plurality of powers, states, and operations. In other words, to quote the enumeration with which Treatise 53 (I.1) opens, these are 'pains and pleasures, fears and audacities, passions, opinion, reflection, and thought. ${ }^{12}$

Yet it also allows us to grasp the very principles of reality: soul, Intellect, and the One-Good. For, as Plotinus writes, those three realities also exist in us: in us, not as sensible beings, but as identical with what Plato calls 'the inner man' (V.1 [10], 10. 6-10). Plotinian interiority is therefore simultaneously plural and stratified.

\footnotetext{
${ }^{11}$ Here as below the translation used is that of Armstrong. The following development partly resumes Aubry, 2007.

${ }^{12}$ I.1 [53], 1.1-9. Cf. Aubry, 2004.
} 
It consists in the several powers which form a human soul, but also in the traces left in it by what is superior to it (Intellect and the One).

Plotinus nonetheless admits-and this is an essential and singular point-an immediate grasp of the self, or, rather, the us, the hemeis, by itself. More precisely, he formulates, in two different places, a reflexive question: at the end of the above quoted enumeration that opens Treatise 53, he asks 'That which acts as overseer and carries out the investigation and comes to a decision about these matters: what sort of thing is it?' (1,9-11). And in Treatise 22 (VI.4), we find another text which opens with this strange question: 'But we... Who, "we"?' $(14,16)$. What emerges here is, indeed, an immediate reflexivity, a relationship of the hemeis to itself which requires neither another subject, nor an object. ${ }^{13}$ However, this immediate relation to oneself does not amount to self-knowledge. Or, rather, it can only be related to the first moment of self-knowledge as distinguished above: that is, the grasp of a multiplicity which must still be distributed between different subjects of attribution. This is why the reflexive question does not bear its answer in itself: to ask 'But we... Who "we"?' is not enough to know who we are; the hèmeis does not grasp itself through its capacity to be conscious of itself. This capacity does not teach it anything about itself, does not give it access to its essence, nor to its identity. In other words, self-consciousness is not equivalent to self-knowledge.

It is much rather an access to 'the whole soul', that is, to the plurality of powers, states and operations already listed. This plurality is progressively reduced, in Treatise 53, to a fundamental duality: polla gar hèmeis, claims Plotinus first $(9,7)$, and then ditton to hemeis $(10,5)$. Treatise 22 , for its part, immediately stresses this duality:

But we... Who, 'we'? Are we that which draws near and comes to be in time? No, even before this coming to be came to be we were there; men who were different, and some of us even gods, pure souls and intellects united with the whole of reality [...] But another man, wishing to exist, approached that man; and when he found us-for we were not outside the All-he wound himself round us and attached himself to that man who was then each one of us [...]; and we have come to be the pair of them, not the one which we were before-and sometimes just the other one which we added on afterwards, when that prior one is inactive and in another way not present. (VI.4 [22], 14. 16-31)

This text describes the hemmeis as made up of two men or, rather, two alternate and alternative presences. It does not consist in the two men at the same time, yet 'sometimes', or 'more than once', neither is it the initial man any longer, but rather

${ }^{13}$ It has been emphasized elsewhere that Plotinus is thereby distinguished from Plato as well as from Aristotle; see Aubry, 2008 (1). 
the second. Those two presences are also described (I shall come back to this point) as two alternative acts: when we are the second man, this means that the first one is no longer active (1. 30). Treatise 22 gives clues about what one should understand by those two men: the first or primeval man is 'man in the Intellect', that is to say soul plus the logos of man. ${ }^{14}$ The second or adventitious man is first designated in chapter 14 of Treatise 22 as 'that which draws near and comes to be in time' (1.16): in the next chapter, the ensouled body will be described in similar words. ${ }^{15}$ Now, and this is the point I would like to stress here, the hemeis is neither of those two: it is neither the separate soul, nor the ensouled body, the 'animal.' ${ }^{16}$ Admittedly, the separate soul is associated with a logos which already contains some individual qualities, but it is without consciousness, memory, or body; ${ }^{17}$ the 'animal', for its part, is body as ensouled by the powers of the World-Soul, not of the individual soul. This is why Plotinus clearly distinguishes it from the hemmeis:

We, however, are formed by the soul given from the gods in heaven and heaven itself, and this soul governs our association with our bodies. The other soul, by which we are ourselves, is cause of our well-being not of our being.

(II.1 [40], 5. 18-21)

This already indicates how we are to understand the affirmation quoted above from Treatise 53, according to which 'the hēmeis is double. This does not mean that the hèmeis is both men together, nor that it consists in their sum. In fact, the hèmeis is more dual than double, in the sense that it can be either one or the other of those two men. Yet neither of the two is really the hemeis: in the first one lies its essential identity, which includes some individual qualities but excludes body, memory, and history; in the second one, the anonymous powers common to all living beings. Thus, to return to our concern, not only does conversion towards interiority and the reflexive question provide access to a mere duality, but they also miss their object, since the hemeis does not grasp itself as identical with this duality.

Another, later, text may shed light on this point as well as on the passage from Treatise 22. In Treatise 49 [V.3], the hèmeis is designated as 'to kurion tēs psukhēs', 'the principal part of the soul, in the middle between two powers, a worse and a better' $(3,35-38)$. These two powers are then identified with sensation and thought. Although they are not 'us', however, they can be called 'ours':

But it is generally agreed that sense-perception is always ours-for we are always perceiving-but there is disagreement about Intellect, both because we do not always use it and because it is separate. (V.3 [49], 3. 40-42)

\footnotetext{
14 This is how Treatise 38 [VI.7], 5, 2-3 characterizes it (see also Pierre Hadot's commentary, Hadot, 1988: 221). About the individual's intelligible preexistence in the logos, cf. Aubry, 2008 (2).

15 VI.4 [22], 15, 12-13. $\quad{ }^{16}$ This point is developed in Aubry, 2008 (1).

17 See for instance IV.3 [27], 32. 17-21; IV.4 [28], 2. 1-8.
} 
The formulations we read here are very close to those of Treatise 22: like the two men, the two powers corresponding to them (sensation defining the living being, thought the separate soul) are the subject of an alternative 'use'. Just as we are 'more than once' the adventitious man, we 'always feel'. And just as the first man, in Treatise 22, was said to be 'inactive' when the second man is active, we read here that 'we do not always use it [i.e. Intellect]'.

But what also appears clear is that the two men or the two powers the hemeis finds in itself when it wonders who it is, are not 'us' but 'ours. In this first moment of self-knowledge, we don't yet know who we are, but only what is 'ours'.

The following question must then be asked: how can that which is only ours become 'us'? We have seen that the notions of activity and use appeared successively in treatises 22 and 49 . Plotinus closely associates both with the notion of consciousness. In Treatise 53, use is identified with actualization. To use is to drive something from potentiality to actuality, from dunamei to energeiai. And it is consciousness that governs this operation. Thus, Plotinus writes in chapter 11 (1. 3-4): 'The higher principles are active in us when they enter the middle region.' The following question is then asked:

But then, does not the 'we' include what comes before the middle?-Yes, but there must be a conscious apprehension (antilēpsis) $)^{18}$ of it: we do not always use all that we have, but only when we direct our middle part towards the higher principles or their opposite, or to whatever we are engaged in bringing from potentiality or state to act. (I.1 [53], 11, 4-8)

Consciousness, as long as it governs the actualization or use of a specific power, sensation, or thought, is therefore that by which what was only 'ours' becomes 'us'. In other words, it is what governs the identification of the hemeis with one or another of the two men in which it consists.

Two points must be stressed:

- First, consciousness here appears as an operator of selection, rather than of totalization. $^{19}$

- Second, and we shall concentrate on this point, consciousness is not the revelation of an identity, but the means to an identification or, rather, to two distinct and exclusive identifications. For Plotinus, we are not conscious of what we are, but, rather, we are (in act) what we are conscious of (an animal, a being of pure sensation, when we are only aware of the activity of the

\footnotetext{
18 Along with this word, one also finds sunaisthēsis, parakolouthēsis, sunēsis, sunthesis. For an attempt of classification, see H. R. Schwyzer, 1960; A. C. Lloyd, 1964; E. Warren, 1964.

19 It is not the case in other texts, such as V.I [10], 12. 5-10 (quoted below, 217), where consciousness is treated as an operator of totalization.
} 
ensouled body, a separate soul when we become aware of the unceasing activity of pure thought). If the reflexive question leads to the acknowledgment of a duality, consciousness, for its part, amounts to the choice of an identity. For this reason, it must be associated with the two last moments of the declension, by Plotinus, of the process of self-knowledge: 'Know what governs in you', and 'Know what, in you, is really you'. Awareness is what governs this selective and hierarchizing moment of self-knowledge. Now, the remarkable thing is that the relation between consciousness and selfknowledge does not determine the relationship to oneself as primordially cognitive, but rather as practical. The really cognitive moment is only the first one, that is, the consciousness of the various powers, or of the two men, in whom the hemeis consists; but this first moment must leave room for a choice, a selection, and an exclusive orientation of consciousness. For that matter, Plotinus explicitly associates this moment with the cathartic degree of virtue. ${ }^{20}$

I would like, before coming to the second part of my chapter, to stress one last point: Plotinus's dissociation between consciousness and substance. As we just saw, consciousness is closely linked to the hemmeis. But this does not mean that it identical with it: in Treatise 53, the hēmeis is designated as that which governs its orientation, up or down, towards the separate soul or towards the animal. In Treatise 10 (V.1), Plotinus also says not that we are consciousness, or that consciousness is us, but, simply, that 'we are linked to it':

For not everything which is in the soul is immediately perceptible, but it reaches us when it enters into perception; ${ }^{21}$ but when a particular active power does not give a share in its activity to the perceiving power, that activity has not yet pervaded the whole soul. We do not therefore yet know it, since we are accompanied by the perceptive power (meta tou aisthêtikou) and are not a part of the soul but the whole soul. (V.1 [10], 12. 5-10) ${ }^{22}$

The hemeis cannot be identified with dianoia, any more than it can be with consciousness; once again, it is merely associated with this faculty. In Treatise 53, Plotinus writes, with regard to opinion and reasoning, that 'this is precisely where we mostly are' $(7,15-16)$. We saw that, in Treatise 49 , this situation was designated as intermediate between two powers, sensation and thought. But the hèmeis was designated at the same time as that which can use one way or the other. This is why I have elsewhere called it a 'subject without identity', or else a power of choice

${ }^{20}$ See I.2 [19], 4. 19-25.

${ }^{21}$ Here, aisthēsis. $\quad{ }^{22}$ See Pierre Hadot's commentary, 1997, chap. II, 34. 
and identification. ${ }^{23}$ The hemmeis cannot be identified with a specific power of the soul, any more than with one or another of the two men who cohabit in it. ${ }^{24} \mathrm{On}$ the contrary, it is that which identifies with one or the other, according to the orientation it gives to its consciousness. Of these two men, however, only the first one, the separate soul, is a substance, an ousia.

At the end of this first stage, we can thus notice that Plotinus both makes use of the notions that were to be articulated by the 'Cartesian moment', and clearly distinguishes them: ${ }^{25}$ the 'we' is associated with consciousness, but is not identical with it; it is endowed with reflexivity, but this reflexivity is not equivalent to

${ }^{23}$ This description is contested by Tornau, 2009, 332-60: 334, n. 2. That the hemeis is not an ousia is nonetheless what appears for instance in I.1 [53], 2 where one can read an explicit distinction between 'soul' and 'essential soulness', $\psi v \chi \gamma^{\prime}$ and $\psi v \chi \hat{\eta} \hat{\epsilon} \in \hat{i} v a \iota$, that is to say between the soul linked with body, to which sensation, opinion, and reflection can be attributed, and the separate soul, which is, for its part, a

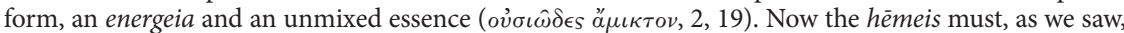
be associated with the former as distinct from the latter. Besides, even though I think it can be characterized as intermediary between two powers which are also two potential identities, I do not describe the hèmeis as a 'pure potentiality', as Tornau writes, but as a power of choice and self-determination (For this link between hèmeis and proairesis, see Aubry, 2004, 302-4). Along the same lines, see Sorabji, 2006, 119, who writes that the self, for Plotinus, is something that you yourself can shape rather than something that has just been given you by nature', and traces this idea back to the Stoics, as well as O'Daly, 1973, 49: 'The self is not a static datum, even if it exists potentially in its entirety: it is essentially a faculty of conscious determination, a mid-point which can be directed towards the higher or towards the lower'

${ }^{24}$ About the hemmeis being irreducible both to the separate soul and to the dianoia, I refer to the answer given in Aubry, 2008 (1), 118, n. 29 to Chiaradonna's article in Aubry and Ildefonse 2008, n. 22, 284. As we saw, the hemmeis can be situated at the level of the dianoia, but it can also identify with the separate soul. Therefore it is not identical with 'soul': one must, into soul, distinguish between the dianoia and the separate soul, and the hèmeis is neither one nor the other but the principle of the passage from one to the other. As L. Lavaud writes: 'It is the very gap between us and the soul that allows the appropriation of the Intellect, its becoming "ours"' (2002: 188).

${ }^{25}$ For a Cartesian reading of Plotinus, see Rappe, 1996. One could ask, as Peter Adamson did when this conference took place in London, whether one should not recognize, already at the level of the dianoia, a kind of Plotinian cogito whose formulation would be as follows (here I quote from Adamson's response to my paper): 'I cannot doubt that here is a somehow united multiplicity of capacities, even though I can doubt which, if any, of these multiple capacities is me. This Plotinian cogito would be the immediate and indubitable intuition of my inward multiplicity. It is certainly very interesting to look for a Plotinian cogito at the level of the dianoia, since the comparison with Descartes is usually made only at that of the Intellect. Still, and along with those already developed, two points must be stressed which may help to evaluate the irreducibility of Plotinus's approach to Descartes': first, even though Plotinus admits, as we saw, an immediate reflexivity, this can't be considered an intuition, since the kind of consciousness that obtains at the level of the dianoia is closely associated by Plotinus with discursivity, logos and imagination (see below, n. 27); second, and this may be the most important point, not only is this immediate reflexivity not an intuition of the essence, but none of the multiple capacities it has as its object can be referred to the essence, i.e. to thought. Plotinus could not write, as Descartes does in the 'Second Meditation': 'Sed quid igitur sum? Res cogitans. Quid est hoc? Nempe dubitans, intelligens, affirmans, negans, volens, nolens, imaginans quoque, et sentiens' (Meditationes de prima philosophia, ed. Adam \&Tannery, Euvres de Descartes VII, Paris: Vrin, 1996, 28). Even though they are objects of consciousness, judgement, opinion, imagination, and sensation cannot be brought back to thought nor considered as its modes. Being conscious of them is not enough to attribute them to a unique subject nor to consider myself as this subject. Those multiple capacities must be distributed between different subjects, that is to say, between different levels or powers of the soul (sensation and imagination belong to soul as linked with body, judgement, to the dianoia, thought, to the separate soul). It is this Plotinian distinction between different levels of the soul, which also are different subjects of attribution, that forbids any conception of 'subjectivity'. 
self-knowledge; it does not give access to the essence, but to several powers and a fundamental duality; of the two men that make up the hemeis, only the first one constitutes its essence and is itself a substance. However, the hemeis is not immediately identical with this man; it can only identify with him by making a selective use of its consciousness, so that the Delphic imperative should be understood here as a practical imperative: 'Become what you are', rather than 'Know who you are'.

\section{Self-Knowledge in the Intellect}

In Treatise 49, Plotinus distinguishes between two modes of self-knowledge:

The man who knows himself is double, one knowing the nature of the reasoning which belongs to the soul, and one up above this man, who knows himself according to Intellect because he has become that Intellect; and by that Intellect he thinks himself again, not any longer as man, but having become altogether other and snatching himself up into the higher world. (V.3 [49], 4. 7-13)

We must therefore distinguish between self-knowledge in the soul, that is to say, here, in dianoia, and self-knowledge in the Intellect. The principle of passage from one to the other is, once again, the hemeis (which is another proof of its irreducibility to dianoia): the Intellect, which was said to be 'ours', can become 'us' at the end of the process of actualization-identification described above. Or rather, as Plotinus puts it, 'if it is really ours and if we belong to it, then we shall know both the Intellect and ourselves'. But for this to happen, we must 'become Intellect' and 'abandon all the rest which belongs to us' (V.3 [49], 4. 29-30). The question of what this 'rest' is, that is to say what remains of the hemeis in the Intellect, has often been discussed. ${ }^{26}$ I would like for my part to ask once again the question that guides me here: that of the articulation or distinguishing, by Plotinus, of the fundamental terms of the Cartesian complex. For matters are not the same in the soul and in the Intellect. I shall focus on two points:

- First, the dissociation between consciousness and self-knowledge, whose formulation, at the level of the Intellect, is the reverse of that which applied to the dianoia and the hemeis: we should no longer say that self-consciousness does not amount to self-knowledge, but rather that self-knowledge is independent of consciousness;

- Second, the identification between self-knowledge, thought, and substance, an identification that is based on the concept of energeia.

\footnotetext{
${ }^{26}$ See in particular Tornau, 2009, as well as Remes, 2007.
} 
We read, in Treatise 31, a description of what it means to 'become Intellect':

Making no more separation, $<$ he $>$ is one and all together with that god silently present, and is with him as much as he wants to be and can be. But if he returns again to being two, while he remains pure he stays close to the God, so as to be present to him again in that other way if he turns again to him. In this turning he has the advantage that to begin with he sees himself (aisthanetai), while he is different from the god; then he hastens inward and has everything, and leaves perception behind in his fear of being different, and is one in that higher world; and if he wants to see by being different, he puts himself outside.

(V.8 [31], 11. 5-13)

This text describes an alternation between presence and consciousness, as well as between unity and duality, identity and difference with 'the god' (Intellect). Selfconsciousness is associated with duality and difference. We already saw above how Plotinus considers it sometimes as a power of totalization, sometimes as a power of selection. Here, it appears under another aspect: as a factor of distance and division. ${ }^{27}$ Consciousness is no longer the way to identity with oneself but, quite the contrary, the cause of an estrangement. Such a consciousness, still linked to sense-perception, must make way for another kind of consciousness which does not introduce any distance between 'subject' and 'object': 'This is a sort of intimate understanding (sunesis) and perception of a self (sunaisthèsis hautou) which is careful not to depart from itself by wanting to perceive too much' (V.8 [31], 11.23-24).

This non-reflexive consciousness, which also is radically separated from senseperception, is the only one that amounts to self-knowledge: 'We have no perception of what is our own, and since we are like this we understand ourselves best when we have made our self-knowledge one with ourselves' (V.8 [31], 11. 31-33).

We must therefore distinguish between two modalities of consciousness as well as, correlative to them, two modalities of self-knowledge: in the hemeis, consciousness is, first, knowledge of its constitutive duality, then, choice of an identity; in the Intellect (or in the hèmeis considered as identical to the first man and to the separate soul), consciousness is pure presence to, and pure identity with, oneself, but with oneself as divine and no longer as man. ${ }^{28}$

Self-knowledge can also be predicated of the Intellect itself. More precisely, it must be so, since Intellect, like soul, is a multiple being. ${ }^{29}$ But we are then

\footnotetext{
${ }^{27}$ In the same lines, see also IV.3 [27], 30. 7-15, where consciousness is associated with logos and imagination, phantastikon, as well as I.4 [46], 10. 28-31, where Plotinus writes: 'Conscious awareness is likely to enfeeble the very activities of which there is consciousness; only when they are alone are they pure and more genuinely active and living.'

${ }^{28}$ Cf. Plato, First Alcibiades, 133c.

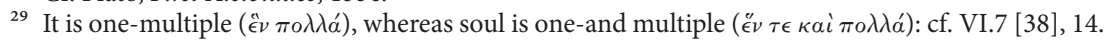
11-12 and IV.2 [2], 2.40.
} 
confronted with another aporia: the one formulated by Sextus Empiricus, according to which it is impossible for a compound being, and particularly for the intellect, to have knowledge of itself: either it will know itself by itself as a whole, but in this case its knowledge will have no object, or else it will know itself by a part of itself, but in this case it won't know this very part of itself. ${ }^{30}$ In order to solve this aporia, Plotinus will show that the distinction between what knows and what is known, intellection and intelligible, does not apply to the Intellect. In other words, he will formulate a model of knowledge that establishes identity between what knows and what is known.

This model rests on a re-use of the Aristotelian notion of energeia. ${ }^{31}$ But it is also built against the notion of passive intellect: according to Aristotle, the noūs pathetikos receives the form, to which it is identical only in potentiality, so that its relationship to the intelligible is the same as that of the sense to the sensibles. ${ }^{32}$ Plotinus claims, in contrast, that 'we must take this Intellect to be, not that which is in potentiality or that which passes from stupidity to intelligence [...] but that which is actually and always intellect' (V.9 [5], 5. 1-4). Thus, Intellect is not actualized, as is sense by the sensibles, or the noūs pathetikos by the intelligibles, but it is always already in act, energeiai. But this implies that it should already have its object within itself, instead of extracting it from the sensible (V.9 [5], 5. 6-23) or finding it in an intelligible distinct from itself.

In order to express this interiority of the intelligible to the Intellect, Plotinus speaks of 'possession' and uses the verb ekhein; he thus takes up the Platonic meaning of the hexis which, in the Theaetetus, is opposed to ktesis as effective grasp to mere disposition. ${ }^{33}$ Plotinus opposes possession to the imprint, tupos. ${ }^{34}$ There is an imprint when knowledge is applied to an external object, which, as such, is not necessarily given to it, and in relation to which it is passive. This is why dissociating the intelligibles from the Intellect amounts to characterizing thought on the model of the imprint, and, ultimately, to confusing noèsis and aisthesis (V.5 [32], 1. 20-27). Conversely, the interiority of the intelligibles to the Intellect ensures an immediate, necessary, and active knowledge. To think, in the real sense of the term, is to possess, ${ }^{35}$ to be one with one's object, which does not mean to be absolutely one, for, in this last case, thought is no longer necessary.

\footnotetext{
${ }^{30}$ Sextus Empiricus Adversus Mathematicos VII, 310-12 together with Plotinus, V.3 [49] 1. 5-12; 5. 1-15. Plotinus's answer to Sextus is analysed by R. T. Wallis, 1987; see also D. O'Meara, 2002.

31 This point is developed in Aubry, 2007.

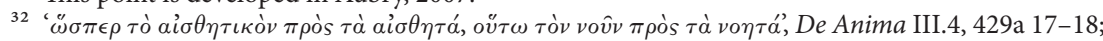
see also III.8, $431 \mathrm{~b} 26-8$.

33 Theaet. 197b-198d.

34 Theaet. 191d s.; cf. V.3 [49], 5. 21-5: 'The contemplation must be the same as the contemplated and Intellect the same as the intelligible; for if it is not the same, there will not be truth; for the one who is trying to possess realities will possess an impression (tupon) different from the realities, and this is not truth.

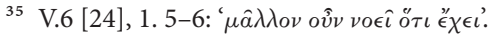


Thus, even more than interiority, one must assert the identity of the intelligibles with the Intellect. And, once again, this does not mean only that the Intellect and the intelligible become unified through the act of intellection, but that they are immediately one and the same act, one and the same energeia (VI.6 [34], 6. 19-26). For the intelligible also is the first substance, the prōte ousia; and, as such, it is also prōte energeia; but the first act, which also is the best one, is intellection. And the Intellect, in its turn, if it is act and not mere potentiality, must be intellection; therefore, it is identical with this very act, with which being and the intelligible are one as well (V.3 [49], 5. 35-43).

The argument of Treatise 49 thus leads to the position, in energeia, of the identity of being, intelligible, and the Intellect. Sextus's aporia about self-knowledge can thus be dismissed.

But Plotinus also uses the same means to answer another aporia: that of the Charmides, according to which self-knowledge, progressively defined as science of itself, is an empty, object-lacking science. ${ }^{36}$ The problem of the Charmides is also clearly formulated in Treatise 49:

Will it know itself (gnōsetai heauton) in such a way that it knows the intelligibles alone but does not know who it is, but will know that it knows the intelligibles which belong to it, but will not yet know who it is? Or will it know both what belongs to it and itself? (V.3 [49], 1.24-27)

Self-knowledge is not empty reflexivity. It is not only knowledge that one knows, but knowledge that one is, or, more precisely, knowledge, by the Intellect, of the totality of the intelligibles and of ousia. However, neither is self-knowledge a mere addition to knowledge of the object, according to the model formulated by Aristotle in book Lambda of the Metaphysics (9, 1074b36): identical in act, but without actualization, to the intelligibles and to the ousia, the Intellect, while thinking the intelligibles, also thinks itself. ${ }^{37}$

This knowledge identical with its object is, for Plotinus, what defines truth: 'Real truth is also there, which does not agree with something else, but with itself, and says nothing other than itself' (V.5 [32], 2. 18-19). Truth is less conformity than identity, self-transparency of that thought which is indissolubly the first essence and the first intelligible.

Plotinus thus asserts, in the Intellect, and through the notion of energeia, the identity between self-knowledge, self-consciousness, and ousia. While thinking

\footnotetext{
${ }^{36}$ Charmides 170c-171c. About the reformulation, by Plotinus, of the aporias of the Charmides, see M.-F. Hazebroucq, 2002.

${ }^{37}$ L. P. Gerson, 1997, thus stresses that, in the case of the Intellect, Plotinus admits a 'self-evident cognitive state', and that, in this paradigmatic case, self-knowledge and self-reflexivity are identical. P. Remes 2007, 174-5, sketches for her part a comparison between some Plotinian texts about the incorrigibility of self-thought (III.9 [13], 6. 1-2 and V.8 [31], 11, 37-8) and the Augustinian and Cartesian cogito.
} 
itself, Intellect knows itself as knowing, and also knows the being it is. Plotinus claims not only the possibility of this mode of knowledge (against Sextus), and its validity (against the Charmides), but that it is the very model of truth. However, he does not confer on it the value of a principle: if the Intellect thinks itself, it is precisely because it is not the first principle, because it is not the One. What is more, it only thinks itself for lack of the One. ${ }^{38}$

This is why, ultimately, the structure of self-knowledge is the same for the soul and for the Intellect. Just as, for the hemeis, to know itself according to the Intellect is to think itself 'not any longer as man, but having become altogether other and snatching himself up into the higher world, drawing up only the better part of the soul' (V.3 [49], 4. 10-13), to know itself, for the Intellect, is to know its own inadequacy to the One. Self-knowledge is nothing more than a substitute for unity. For this reason, it is not closure nor perseverance into oneself. ${ }^{39}$ Knowing oneself, for Plotinus, is not as much knowing what oneself is as knowing where one comes from: 'He who has learnt to know himself will know from whence he comes' (VI.9 [9], 7. 33-34). This is why the Delphic imperative is, as we saw, immediately linked to the problem of the one and the many, so that it immediately receives an ontological reading: to know oneself is to be able to situate oneself in the order of reality, that is to say, both to count the multiplicity one is made of, and to evaluate the superior unity one comes from. But, ultimately, one must come back to this greater (for the hemeis converted to the Intellect) or ultimate (for the Intellect converted to the One) unity. For this reason, the Delphic precept appears as an invitation not as much to know one's limits ${ }^{40}$ as to overcome them. We don't so much have to coincide with ourselves as to conform ourselves to an excess; not so much to secure our identity as to identify with what we come from; we don't have to know what we are, but, rather, what we can be, and which both exceeds and founds us.

\section{An Anti-Cartesian Plotinus: Ralph Cudworth}

These analyses may help us to better understand why Plotinus cannot be enlisted either for the ancient thought of the self, nor for the modern philosophies of

\footnotetext{
${ }^{38}$ See for instance VI.7 [38], 41. 21-2: 'If it <the Intellect> was only one, it would have sufficed to itself and would not have needed to get understanding.' This point must be stressed as one of those which forbid any Cartesian reading of Plotinus: even if one can compare the Intellect's self-knowledge with Descartes's incorrigibility, it does not have the same systematic function as the cogito, since it is not a principle but, on the contrary, the very sign that the Intellect is not the Principle.

39 As is, for instance, this kind of relationship to oneself that the Stoics called oikeiōsis: both an immediate reflexivity and the corporeal and sentient self's appropriation to itself.

${ }^{40}$ That what, as is well known, its original meaning, as well as that of the other Delphic precepts, particularly the $\mu \eta \delta \dot{\epsilon} \nu$ a $\alpha a v$ : 'Know thyself', that is to say 'Know what your limits are', in order not to go beyond them. Verbeke, 1997, also underlines that Plotinus's interpretation of the Delphic precept breaks with this prevention from hubris.
} 
consciousness and the subject. He must be distinguished from the former insofar as he accepts an immediate reflexivity, a direct access to interiority. But, unlike the latter, he does not confer on self-knowledge the value of a principle. In the soul, self-consciousness is neither self-knowledge nor identity with the essence; in the Intellect, self-knowledge is accompanied by a kind of self-consciousness, and grounds a model of truth, but it is only a substitute for the One, the first principle which, as absolutely simple, does not need to think or to know itself.

Plotinian philosophy nonetheless appears as a decisive source of inspiration for a Modern who is also, in many respects, a Cartesian, but who found in Plotinus a basis to criticize some fundamental aspects of Descartes' thought and, in particular, his philosophy of the self.

Ralph Cudworth's (1617-88) main purpose was to oppose voluntarism, i.e. those conceptions of divine omnipotence which see in it both an exclusive cause and a sovereign arbitrariness. ${ }^{41}$ Against such notions, he opposes the inseparability, in God, of will and understanding; and to express this, he appeals to Plotinian images:

The Wisdom of God is as much God as the Will of God [...] Now, all the Knowledge and Wisdom that is in Creatures, whether Angels or Men, is nothing else but a Participation of that One Eternal, Immutable, and Increated Wisdom of God, or several Signatures of that one Archetypal Seal, or like so many reflections of one and the same Face, made in several Glasses, whereof some are clearer, some obscurer, some standing nearer, some farther off. ${ }^{42}$

Against the absolutism of the first cause and divine omnipotence, Cudworth postulates immanent powers or plastic natures, which operate as an intermediary between divine action and nature. ${ }^{43}$ While accepting Cartesian mechanism, he admits, alongside those plastic natures, some immanent principles of motion, which are so many centres of 'self-activity' and 'internal energy'. Cudworth thus replaces the dualism of mind and body, by that of force and matter, activity and passivity, or again life and extension. ${ }^{44}$ Indeed, and this is the point I would like to stress, these forces are incorporeal and spiritual, but they are not all endowed with consciousness. We must distinguish, among them, between 'such as either

${ }^{41}$ See Zarka, 1997; Cassirer, 1932. Cudworth explicitly enlists Descartes for this volontarist tradition: cf. A Treatise of Free Will (TFW), XIV: 'And this is that monstrous or prodigious idea or portraiture of God which Cartesius hath drawn out in his metaphysics [...] A being nothing but blind, indifferent, and fortuitous will, omnipotent. And all divine perfections are swallowed up into will.' Cf. A Treatise concerning Eternal and Immutable Morality with A Treatise of Free Will, ed. by S. Hutton, Cambridge University Press, 1996, 187.

${ }^{42}$ Cudworth, A Treatise concerning Eternal and Immutable Morality (TEIM), I, 3, 7, 26. Cf. Plotin I.1 [53], 8. 17-18.

${ }_{43}$ About the legacy, here, of the Plotinian notions of Nature and logos, see A. Petit, 1997.

${ }^{44}$ On this point, see J. A. Passmore, 1990, chap. II. 
acts with express Consciousness and Synaisthesis, and such as is without it, the latter of which is this Plastic Life of Nature. ${ }^{45}$ Cudworth thus rejects the Cartesian identification between thought and consciousness. The plastic natures are endowed with 'cogitation', or rather with a sort of 'Drowse, Unawakened or Astonished Cogitation, ${ }^{46}$ which must be distinguished from 'clear and Express consciousness', or again from 'that duplication, that is included in the Nature of

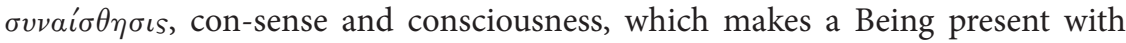
itself, attentive to its own Actions or Animadversive of them....47

Cudworth's criticism of the Cartesian cogito is based on this dissociation between thought and consciousness: the soul's essence cannot be made to reside in thought, nor can thought be identified with clear and distinct consciousness. Moreover, the very strategy of the cogito must be criticized: although every thought we have is not clear and distinct, those which are so can't be doubted. For our clear and distinct perceptions are in fact participation in the divine understanding, or the 'first original knowledge'. And since the latter can't be dissociated from omnipotence, there is no sense in supposing that omnipotence could deceive us about itself. What is more, everything that is clearly perceived also is: 'every clear and Distinct perception is an entity or truth. ${ }^{48}$ And such a clear perception in its turn is not an effect of omnipotence within us, but:

an active Exertion of the Inward Strength, Vigour, and Power of the Mind, displaying itself from within; and the Intelligible Forms by which things are understood or known, are not stamps or Impressions passively printed upon the Soul from without, but Ideas vitally protended or actively exerted from within itself. ${ }^{49}$

Cudworth calls this process 'reminiscence, and quotes Plotinus again. The fact is that one cannot fail to be struck to find here some of the articulations we have been trying to make clear earlier: the identity, at the level of an intellectual knowledge characterized as a participation in the intelligible, between thought and consciousness; ${ }^{50}$ their dissociation at the level of soul.

But it is precisely Cudworth's conception of the soul which appears as the most remarkable, when compared to that of Descartes, as well as the closest to Plotinus. It is immediately placed under the banner of ancient thought, and the aegis of the 'Know thyself'. ${ }^{11}$ For Cudworth as for Plotinus, however, conversion towards

\footnotetext{
${ }^{45}$ Cudworth, The True Intellectual System of the Universe (TIS), Hildesheim: Georg Olms Verlag, 1977, I, 3, 159.

${ }^{46}$ Cudworth, TIS, I, 3, 160. Here again, the formula echoes Plotinus, III.8 [30], 4. 27-28.

${ }^{47}$ Cudworth, TIS, I, 3, $159 . \quad{ }_{48}^{48}$ Cudworth, TIS I, 4, 718.

${ }^{49}$ Cudworth, TEIM, IV, 1, 1, 73-74.

${ }^{50}$ We must nonetheless specify that Cudworth refuses to consider the intelligible essences as real ousiai: those essences are created, so that the Neoplatonists were, according to him, wrong to substantify them: see on this point L. Gysi, 1962, chap. III, as well as M. Baldi, 1997.

${ }^{51}$ Cf. J.-L. Breteau, 1983, 105-15: 109.
} 
interiority first amounts to the discovery of internal multiplicity: far from being

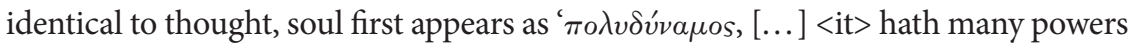
or faculties [...]; it can and doth display itself in several kind of energies as the same air and breath in an organ, passing through several pipes, makes several notes. $^{52}$ This last simile is more Stoic than Plotinian, since it evokes pneuma. And the fact is that Cudworth calls the leading part of the soul hegemonikon, which also is 'that which is properly ourselves'. He considers it as a power both of reflexivity and of tension, by which 'the soul is comprehending itself [...] and holding itself, as it were, in its own hand, as if it were redoubled upon itself, having a power of intending or exerting itself more or less. ${ }^{53}$ At the same time, however, this tension is essentially a tension towards the Good, which is accomplished in free will rather than in freedom of indifference. ${ }^{54}$ In soul, as we saw, those multiple powers go together with what Cudworth calls a 'potential omniformity', which is a power of participation in the Intellect or, again, the 'ectypal print', in soul from 'one Archetypal Intellect.'.

It is in this articulation of power and potentiality that the Plotinian legacy appears most clearly: like the Plotinian hemeis, the Cudworthian self consists of several powers, some of which are also the traces of a superior principle within it, and the means for an elevation to the Intelligible and a tension towards the Good. The characterization of soul as poludunamos is thus linked to an essentially dynamic conception of the subject: the desire for the Good in soul is 'a constant, restless, uninterrupted desire [...] an ever bubbling fountain in the centre of the soul, an elater or spring of motion, both a primum and a perpetuum mobile. ${ }^{56}$

This may, moreover, be the most anti-Cartesian point: since soul is defined by life more than by thought, and thought is dissociated from consciousness, the subject is no longer characterized as that which grasps itself in the instantaneity of the cogito, but rather as that which continually displays its power, which 'always spins out' the 'thread of life. ${ }^{57}$ The Cartesian cogito appears suddenly, in a fragmented instant; and, outside of it, the subject has no access to its own existence. To ensure this existence, it must appeal to the guarantee of divine omnipotence. ${ }^{58}$ The model Cudworth proposes is not only different from but also opposite to the Cartesian one: the continuous power of life contrasts with the point-like actuality of the cogito, and the tension of the self towards a God whose omnipotence

${ }^{52}$ Cudworth, $T F W, 7,171$.

${ }^{53}$ Cudworth, TFW, 10, 178. Cf. SVF I 66 and II 802. $\quad{ }^{54}$ As stressed by J.-L. Breteau, 1997.

${ }^{55}$ Cudworth, TEIM, IV, 4, 11, $131 . \quad{ }^{56}$ Cudworth, TFW, 8, 173.

${ }^{57}$ Cudworth, TFW, 8, 172.

${ }^{58}$ Cf. Principia philosophiae I, 21; Meditationes - Secunda: 'Ego sum, ego cogito; certum est. Quandiu autem? Nempe quandiu cogito; nam forte etiam fieri posset, si cessarem ab omni cogitatione, ut illico totus esse desinerem ' (ed. Adam \&Tannery: 27); - Tertia: 'Quoniam enim omne tempus vitae in partes innumeras dividi potest, quarum singulae a reliquis nullo modo dependent, ex eo quo paulo ante fuerim, non sequitur me nunc debet esse, nisi aliqua causa me quasi rursus creet ad hoc momentum, hoc est me conservet' (AT: 48-49). See on this point the analysis of J.-L. Marion, 1986, 158ff. 
cannot be separated from understanding and will, contrasts with the dependence upon a primordially omnipotent God.

Finally, and this is the last aspect under which Cudworth can be considered as the heir of Plotinus, the subject grasps itself not so much through consciousness and self-knowledge as through self-determination..$^{59}$ Ultimately, consciousness itself is less 'self-comprehensive, self-reflexive, self-recollective' than 'self-determinative.60 And it is finally in free will as choice of the Good, that the relationship of the subject to itself reaches completion. Thus, the practical inflexion of the 'Know thyself', which we already noticed in Plotinus, can be found again here.

This is why we can say that the remarkable articulation by Plotinus of the notions of self-knowledge, self-consciousness, and subject, while it is no longer ancient but not yet modern either, nevertheless opens the way, inside modernity, for a path that is an alternative to Cartesianism.

\section{References}

Aubry G., 2004, Plotin. Traité 53 (I, 1), Introduction, translation, commentary, and notes, Paris: Cerf.

Aubry G., 2007, 'Conscience, pensée et connaissance de soi selon Plotin: le double héritage de l'Alcibiade et du Charmide', Etudes Platoniciennes IV, 163-81.

Aubry G., 2008 (1), 'Un moi sans identité? Le hēmeis plotinien', in Le moi et l'intériorité, edited by G. Aubry and F. Ildefonse, Paris: Vrin 2008, 107-25.

Aubry G., 2008 (2), 'Individuation, particularisation et détermination selon Plotin', Phronesis 53, 271-89.

Aubry G., 2009, 'Lempreinte du Bien dans le multiple: structure et constitution de l'Intellect plotinien', Etudes philosophiques 3, 313-31.

Aubry G., and Ildefonse F. (eds), 2008, Le moi et l'intériorité, Paris: Vrin.

Baldi M., 1997, 'Cudworth versus Descartes: platonisme et sens commun dans la critique des Méditations', in The Cambridge Platonists in Philosophical Context: Politics, Metaphysics and Religion, edited by G. A. J. Rogers, J.-M. Vienne and Y.-C. Zarka, Dordrecht: Kluwer, 173-83.

Billier J.-C., 2009, 'Introduction' to V. Descombes and C. Larmore, Dernières nouvelles du Moi, Paris: PUF, 7-39.

Breteau J.-L., 1983, 'La conscience de soi chez les Platoniciens de Cambridge', in Genèse de la conscience moderne, edited by R. Ellrodt, Paris: PUF, 105-15.

\footnotetext{
${ }^{59}$ Cudworth, TFW 19, 201: 'That which is conscious of itself, reflexive upon itself, may also well act upon itself, either as fortuitously determining its own activity or else as intending and exerting itself more or less in order to the promoting of its own good.'

${ }^{60}$ Cf. Breteau, 1983, 114-15.
} 
Breteau J.-L., 1997, 'La Nature est un art'. Le vitalisme de Cudworth et de More', in The Cambridge Platonists in Philosophical context: Politics, Metaphysics and Religion, edited by G. A. J. Rogers, J.-M. Vienne, Y.-C. Zarka, Dordrecht: Kluwer, 145-57.

Brunschwig J., 1983, 'Aristote et l'effet Perrichon', in La Passion de la raison. Hommage à Ferdinand Alquié, edited by J.-L. Marion, Paris: PUF, 360-77.

Cassirer E., 1932, Die Platonische Renaissance in England und Die Schule von Cambridge, Leipzig: Teubner.

Chiaradonna R., 2008, 'Plotino: il “noi” e il NOŪS (Enn. V, 3 (49) 8, 37-57)' in Le moi et l'intériorité, edited by G. Aubry and F. Ildefonse, Paris: Vrin, 277-93.

Courcelles P., 1974, Connais-toi toi-même; de Socrate à Saint Bernard, Paris: Etudes Augustiniennes.

Cudworth R., 1996, A Treatise concerning Eternal and Immutable Morality with A Treatise of Free Will, edited by S. Hutton, Cambridge: Cambridge University Press, 1996.

Cudworth R., 1678, The True Intellectual System of the Universe, Hildesheim: Georg Olms Verlag, 1977.

Descartes R., 1641, Meditationes de prima philosophia, in CEuvres de Descartes VII, edited by C. Adam and P. Tannery, Paris: Vrin, 1996.

Descombes V. and Larmore C., 2009, Dernières nouvelles du Moi, Paris: PUF.

Dixsaut M. (ed.), 2002, La Connaissance de soi. Etudes sur le Traité 49 de Plotin, Paris: Vrin.

Foucault M., 2001, L’Herméneutique du sujet, Cours au Collège de France, 1981-1982, Paris: Hautes-Etudes-Gallimard-Editions du Seuil.

Gerson L. P., 1997, 'Introspection, self-reflexivity, and the essence of thinking according to Plotinus', in The Perennial tradition of Neoplatonism, edited by J. J. Cleary, Leuven: University Press, 153-73.

Gill C. J., 2006, The Structured Self in Hellenistic and Roman Thought, Oxford: University Press.

Gysi L., 1962, Platonism and Cartesianism in the Philosophy of Ralph Cudworth, Berlin: Herbert Lang.

Hadot P., 1980, 'Les niveaux de conscience dans les états mystiques selon Plotin', Journal de Psychologie 2-3, 243-66.

Hadot P., 1988, Plotin. Traité 38 (VI, 7), Introduction, translation, commentary, and notes, Paris: Cerf.

Hadot P., 1997, Plotin ou la simplicité du regard, Paris: Gallimard.

Ham B., 2000, Plotin. Traité 49 (V, 3), Introduction, translation, commentary, and notes, Paris: Cerf.

Hazebroucq M.-F., 2002, 'La connaissance de soi-même et ses difficultés dans l'Ennéade V, 3 et le Charmide de Platon', in La Connaissance de soi. Etudes sur le Traité 49 de Plotin, edited by M. Dixsaut, Paris: Vrin, 107-31. 
Lavaud L., 2002, 'Structure et thèmes du Traité 49', in La Connaissance de soi. Etudes sur le Traité 49 de Plotin, edited by M. Dixsaut, Paris: Vrin, 179-207.

Lloyd A. C., 1964, 'Nosce Teipsum and Conscientia', Archiv für Geschichte der Philosophie 46, 188-200.

Marion J.-L., 1986, Sur le prisme métaphysique de Descartes, Paris: PUF.

O’Daly G., 1973, Plotinus's Philosophy of the Self, Shannon: Irish University Press.

O’Meara D., 2002, 'Scepticisme et ineffabilité chez Plotin', in La Connaissance de soi. Etudes sur le Traité 49 de Plotin, edited by M. Dixsaut, Paris: Vrin, 91-103.

Passmore J. A., 1990, Ralph Cudworth: An Interpretation, Bristol: Thoemmes.

Pépin J., 1971, Idées grecques sur l'homme et sur Dieu, Paris: Les Belles Lettres.

Petit A., 1997, 'Ralph Cudworth: un platonisme paradoxal: la Nature dans la Digression concerning the Plastick Life of Nature', in The Cambridge Platonists in Philosophical context: Politics, Metaphysics and Religion, edited by G. A. J. Rogers, J.-M. Vienne, and Y.-C. Zarka, Dordrecht: Kluwer, 101-11.

Rappe S., 1996, 'Self-knowledge and subjectivity in the Enneads', in The Cambridge Companion to Plotinus, edited by L. P. Gerson, Cambridge: Cambridge University Press, 250-74.

Remes P., 2007, Plotinus on Self: The Philosophy of the 'We', Cambridge: Cambridge University Press.

Rogers G. A. J., Vienne J.-M., and Zarka Y.-C. (eds), 1997, The Cambridge Platonists in Philosophical context: Politics, Metaphysics and Religion, Dordrecht: Kluwer.

Schwyzer H. R., 1960, 'Bewusst und Unbewusst bei Plotin', in Les sources de Plotin. Entretiens sur l'Antiquité classique, tome 5, Fondation Hardt, Vandoeuvre/Genève, 341-90.

Sorabji R., 2006, Self: Ancient and Modern Insights about Individuality, Life, and Death, Oxford: Clarendon Press.

Tornau C., 2009, 'Qu'est-ce qu'un individu?', Les Etudes philosophiques 3, 332-60.

Verbeke G., 1997, 'Individual consciousness in Neoplatonism', in The Perennial Tradition of Neoplatonism, edited by J. J. Cleary, Leuven: University Press, 135-52.

Vernant J.-P., 1996, “La mort dans les yeux”, Dialogue avec Pierre Kahn', in Entre mythe et politique, Paris: Seuil, 73-93.

Vernant J.-P., 1989, 'L'Individu dans la cité, in L'Individu, la mort, l'amour. Soi-même et lautre en Grèce ancienne, Paris: Gallimard, 211-32.

Wallis R. T., 1987, 'Scepticism and Neoplatonism', in Aufstieg und Niedergang der römischen Welt: Geschichte und Kultur Roms in Siegel der neueren Forschung II, 36.2., Berlin: W. de Gruyter, 911-54.

Warren E., 1964, 'Consciousness in Plotinus', Phronesis IX, 83-98.

Zarka Y.-C., 1997, 'Critique de Hobbes et fondement de la morale chez Cudworth', in The Cambridge Platonists in Philosophical context: Politics, Metaphysics and Religion, edited by G. A. J. Rogers, J.-M. Vienne, and Y.-C. Zarka, Dordrecht: Kluwer, 39-52. 
